\title{
TANGGUNG JAWAB NOTARIS DALAM MENGELURKAN COVERNOTE DALAM PERJANJIAN PEMBIAYAAN DI PERBANKAN SYARIAH
}

\author{
Desy Amelia Rosyidah \\ Program Studi Magister Kenotariatan PPS Unisma \\ Jalan Mayjen Haryono Nomor 193 Malang \\ Email: desyamelia135@gmail.com
}

\begin{abstract}
Abstrak
Penelitian ini memiliki tujuan untuk memaparkan bagaimana praktek dalam pembuatan covernote serta tanggung jawab dan akibat hukum dari pembuatan covernote yang dijadikan dasar dalam perjanjian pembiayaan di Bank Muamalat Cabang Denpasar. Adapun praktek dalam pembuatan covernote terletak di tahap realisasi pembiayaan yang ada di Bank Muamalat Cabang Denpasar, dan tanggung jawab notaris terletak pada tanggung jawab moral yang menyangkut nama baik notaris serta akibat hukum timbul jika terjadi wanprestasi oleh notaris yang menimbulkan kerugian bagi pihak banksehingga dapat dikenakan sanksi secara hukum perdata maupun adminitrasi.
\end{abstract}

Kata Kunci : covernote, tanggung jawab, akibat hukum, bank syariah.

\begin{abstract}
The aim of this study is to portray the implementation of compiling covernote as well as the notary's responsibility and legal consequences that are used as the basis foundation of financing agreement at Bank Muamalat Denpasar. The implementation of making covernote at Bank Muamalat Denpasar is on the stage of financing realization. The notary's responsibility is the moral responsibility in regard to his reputation and the legal consequences that may emerge if there is a default performed by the notary in which it will harm the bank. Thus, he could receive penalty both civil and administrative law.
\end{abstract}

Keywords: covernote, responsibility, legal consequences, syaria bank

\section{PENDAHULUAN}

Seiring dengan berkembang pesatnya kehidupan bermasyarakat, serta perkembangan teknologi yang semakin maju, maka kebutuhan masyarakat akan jasa seorang notaris pun semakin dibutuhkan. Hal ini terjadi karena adanya keinginan serta kebutuhan masyarakat untuk menyertakan suatu kehendak dengan alat bukti ang autentik. 
Notaris merupakan pejabat umum yang mempunyai kewenangan untuk membuat suatu akta otentik sejauh pembuatan akta otentik tersebut tidak dikhususkan bagi pejabat umum lainnya dan juga mempunyai tugas dan kewajiban untuk memberikan pelayanan dan konsultasi hukum kepada masyarakat yang membutuhkan serta masyarakat secara keseluruhan dalam rangka menciptakan kepastian, ketertiban dan perlindungan hukum sebagaimana tertulis di dalam Pasal 15 ayat (1) Undang-Undang Nomor 2 Tahun 2014 atas Perubahan Undang-Undang Nomor 30 Tahun 2004 Tentang Jabatan Notaris yang menurut pemahaman penulis adalah bahwa kewenangan notaris adalah untuk membuat suatu akta autentik terkait dengan perbuatan, perjanjian dan ketetapan yang telah diatur oleh undangundang atau yang dikehendaki oleh yang berkepentingan yang dinyatakan dalam akta autentik sepanjang pembuatan akta tersebut tidak ditugaskan atau dikecualikan kepada pejabat lain atau orang lain yang telah ditetapkan oleh undang-undang.

Untuk menjadi seorang notaris dibutuhkan persyaratan tertentu, mengingat notaris merupakan jabatan kepercayaan dimana persyaratan tersebut tidak hanya dalam aspek intelektual, namun juga mempunyai keharusan memiliki integritas moral yang tinggi. Hal ini didasarkan pada Pasal 16 ayat (1) huruf a Undang-Undang Jabatan Notaris (UUJN) yang berbunyi "Dalam menjalankan jabatannya, Notaris berkewajiban bertindak jujur, seksama, mandiri, tidak berpihak, dan menjaga kepentingan pihak yang terkait dalam perbuatan hukum”.Dengan adanya persyaratan yang tertuang dalam Undang-undang Jabatan Notaris (UUJN) tersebut besar harapan agar seorang Notaris tidak akan menyalahgunakan wewenang dan kepercayaan yang diberikan kepadanya.

Dengan demikian sangat penting bagi seorang notaris untuk dapat memahami serta menerapkan ketentuan yang telah diatur oleh UndangUndang supaya masyarakat umum yang tidak mengetahui serta kurang memahami aturan hukum dapat mengetahui serta memahami dengan benar sehingga dapat mencegah masyarakat untuk melakukan hal-hal yang bertentangan dengan hukum yang berlaku.

Membuat suatu akta yang otentik merupakan suatu peran yang siginifikan bagi seorang Notaris dan PPAT dalam perbuatan hukum khususnya di dalam ruang lingkup hukum perdata. Karena Notaris dan PPAT merupakan pejabat yang menjadi bagian dari subyek sistem tersebut, negara sebagai pengatur semua aspek kehidupan berbangsa dan bernegara memiliki kelengkapan sarana fisik serta norma-norma khusus yang secara umum diakui dimana pelaksanaannya dapat dipaksakan untuk memenuhi dan membimbing kebutuhan masyarakat khususnya mengatur masalah 
perjanjian. ${ }^{1}$ Wewenang serta tugas seorang Notaris adalah mengatur secara tertulis hubungan-hubungan hukum antara para pihak yang meminta jasa Notaris secara mufakat. ${ }^{2}$ Adanya kewenangan inilah yang dijadikan dasar bagi notaris apabila di kemudian hari lahir suatu peraturan perundangundangan yang mencantumkan klausula di dalamnya yang mengharuskan untuk menggunakan akta autentik.

Notaris sebagai mitra Bank, khususnya Bank Syariah, dalam membuat akta otentik memiliki kewenangan untuk membuat akta yang menunjukkan bahwa telah terjadinya suatu perbuatan hukum oleh para pihak dihadapan Notaris-PPAT. Akta yang telah dibuat oleh Notaris-PPAT merupakan suatu hal penting yang bertujuan untuk melindungi kepentingan bagi para pihak. Salah satunya adalah terkait dengan proses pembiayaan yang ada di perbankan syariah, yang mana akad pembiayaan yang ada pasti melibatkan unsur jaminan yang biasanya berupa tanah. Proses pengurusan yang tidak sebentar serta adanya tuntutan dari nasabah agar mendapatkan dana secepatnya dan juga tuntutan dari pihak bank yang ingin mengeluarkan dana pembiayaan kepada nasabah secepatnya membuat bank khususnya bank syariah meminta notaris untuk mengeluarkan suatu covernote atau surat keterangan dari notaris sebagai pegangan sementara bagi bank dalam proses pencairan pembiayaan dikarenakan notaris belum selesai melakukan tugasnya seperti yang telah tertuang di dalam covernote. Covernote yang dikeluarkan oleh notaris telah banyak dipergunakan dalam praktik perbankan dimana covernote tersebut dijadikan suatu syarat dalam melakukan penarikan pembiayaan karena perbankan lebih mengutamakan pembiayaan dengan jaminan tanah yang kemudian diikat dengan hak tanggungan.

\section{METODE PENELITIAN}

Jenis penelitian yang digunakan adalah jenis penelitian yuridisempiris. ${ }^{3}$ Untuk mengkaji pokok permasalahan, penelitian ini mempergunakan metode penelitian hukum empiris dimana penelitian ini menitik beratkan pada hasil-hasil pengumpulan data yang didapatkan dari narasumber yang telah ditentukan sebelumnya. Pendekatan yang bersifat yuridis-empiris tersebut akan dilakukan dengan mempergunakan bahan hukum primer dan bahan hukum sekunder. Adapun teknik pengumpulan

\footnotetext{
${ }^{1}$ Adnan Buyung Nasution, Inspirasi Pemerintahan Konstusional Indonesia (studi Sosio-Legal atas Konstituante 1956-1959), (Jakarta: Temprint, 2001), hal. 107.

${ }^{2}$ Supardi, Etika dan Tanggung Jawab Profesi Hukum di Indonesia, (Jakarta: Sinar Grafika, 2008), hal. 50

${ }^{3}$ Ronny Hanitijo Soemitro, Pengantar Penelitian Hukum, (Jakarta, Ghalia, 1994). hal. 21.
} 
data yang digunakan berupa wawancara yang dilakukan penulis kepada beberapa narasumber yang terkait yaitu legal staf Bank Muamalat Cabang Denpasar dan juga notaris rekanan dari Bank Muamalat Cabang Denpasar dengan teknik analisis data deskriptif-kualitatif.

\section{PEMBAHASAN}

\section{Praktik Pembuatan Covernote Oleh Notaris}

Perbankan syariah memiliki kegiatan usaha pokok berupa menghimpun dana dari pihak yang kelebihan dana untuk kemudian menyalurkan kembali dana tersebut ke masyarakat yang kekurangan dana dalam jangka waktu tertentu. Bank syariah merupakan salah satu produk perbankan yang berlandaskan sistem perekonomian Islam. Bank syariah dikembangkan pada awalnya sebagai suatu respon dari kelompok ekonomi dan praktisi perbankan muslim yang berupaya mengakomodasi desakan dari berbagai pihak yang menginginkan agar tersedia jasa transaksi keuangan yang dilaksanakan sejalan dengan nilai dan moral serta prinsip-prinsip yang berlandaskan syariah Islam.

Kalau sudah soal moral, dalam kehidupan manusia disadari bahwa yang benar, yang indah dan yang baik itu menyenangkan, membahagiakan, menentramkan, dan memuaskan manusia. Sebaliknya yang salah, yang jelek, dan yang buruk itu menyengsarakan, menyusahkan, dan membosankan manusia. Berdasarkan dua sisi yang bertolak belakang ini, manusia adalah sumber penentu yang menimbang, menilai, memutuskan untuk memilih yang paling menguntungkan (nilai moral) atau merugikan banyak orang (dalam pendekatan norma yuridis), ${ }^{4}$

Pencairan terhadap pembiayaan yang diikuti dengan pemasangan Hak Tanggungan tidak terlepas dari peran notaris sebagai pejabat umum, dimana pengikatan jaminan dalam pembiayaan dengan Hak Tanggungan memerlukan akta notaris sebagai pejabat yang diberi kewenangan untuk membuat akta autentik yang berhubungan dengan tanah, karena berdasarkan Pasal 1 ayat 1 Undang-Undang Nomor 4 Tahun 1996 Tentang Hak Tanggungan Atas Tanah Beserta Benda-Benda Yang Berkaitan Dengan Tanah dimana Hak Tanggungan atas tanah beserta benda-benda yang berkaitan dengan tanah, yang selanjutnya disebut dengan Hak Tanggungan adalah hak jaminan yang dibebankan atas tanah sebagaimana dimaksud dalam Undang-Undang Nomor 5 Tahun 1960 tentang Peraturan Dasar Pokok Agraria, berikut atau tidak berikut benda-benda lain yang merpakan satu kesatuan dengan tanah itu, untuk pelunasan utang tertentu, yang

\footnotetext{
${ }^{4}$ Abdulkadir Muhammad, Etika Profesi Hukum, (Bandung: Citra Adtya, Bandung,
} 1997), hal. 1-2. 
memberikan kedudukan yang diutamakan kepada kreditor terhadap kreditorkreditor lain.

Pesatnya perkembangan bisnis perbankan dan tingginya tingkat persaingan antar bank menyebabkan perbankan mempermudah penyaluran pembiayaan kepada masyarakat, salah satu cara dari bank untuk mempermudah penyaluran pembiayaan kepada masyarakat adalah dengan bank mencairkan pembiayaan setelah adanya covernote sebagai pernyataan sepihak dari notaris. Covernote merupakan surat keterangan yang dikeluarkan oleh notaris, karena notaris dianggap belum dapat menyelesaikan pekerjaannya dalam kaitannya dengan kewenangan serta tugasnya untuk menerbitkan suatu akta autentik. Hal ini dilakukan apabila permohonan terhadap perjanjian pembiayaan persyaratannya belum lengkap sehingga untuk mengatasi kekurangan ini notaris mengeluarkan covernote sebagai pemberitahuan atau keterangan bahwa surat-surat tanah calon debitor masih dalam proses roya, balik nama ataupun proses pemecahan apabila sudah bersertifikat.

Perbankan dalam prakteknya menggunakan covernote sebagai bukti terhadap pengikatan jaminan atau sebagai pegangan sementara bagi bank dalam mencairkan pembiayaan. Covernote muncul berdasarkan praktek kebiasaan dan kebutuhan yang mendesak, kebutuhan tersebut salah satunya adalah untuk mencairkan pembiayaan bagi calon nasabah yang notabene sebagai debitur telah dinyatakan layak untuk memperoleh fasilitas pembiayaan.

Akta autentik yang dibuat dimuka atau dihadapan notaris memiliki pembuktian formal maupun pembuktian material yang dapat menunjang tegaknya prinsip kehati-hatian dalam suatu perjanjian, salah satu contoh perjanjian yang harus menegakkan prinsip kehati-hatian adalah perjanjian dalam pemberian pembiayaan di perbankan syariah.

Selain alasan untuk ketatnya persaingan dalam dunia perbankan syariah serta guna mendapatkan nasabah untuk perputaran dana dan adanya kekhawatiran terkait proses pencairan pembiayaan yang terlalu berbelit-belit dan membutuhkan waktu yang lama yang bisa menimbulkan kekecewaan bagi nasabah yang akhirnya jera dan bahkan bisa mencari bank lain, maka Bank Muamalat Cabang Denpasar harus menggunakan prinsip kehati-hatian dalam pencairan sebuah pembiayaan khususnya pembiayaan KPR yang menggunakan covernote, karena dengan adanya covernote tersebut Bank Muamalat Cabang Denpasar merasa aman dan dapat dijadikan pegangan yang bersifat resmi apabila terjadi pembiayaan yang macet.

Adapun mekanisme dari pembiayaan pada Bank Muamalat Cabang Denpasar dimulai dengan tahap pengajuan pembiayaan tahap penilaian dan investigasi, tahap penawaran terkait dengan jenis pembiayaan yang dipilih 
oleh nasabah dan tahap yang dilakukan untuk menangani pembiayaan yang bermasalah. Prinsip-prinsip pemberian pembiayaan di Bank Muamalat Cabang Denpasar sama halnya dengan perbankan syariah pada umumnya. Sebelum suatu fasilitas pembiayaan diberikan, maka bank harus merasa yakin terlebih dahulu bahwa pembiayaan yang diberikan benar-benar akan kembali sehingga tidak menimbulkan kerugian. Keyakinan tersebut diperoleh dari hasil penilaian pembiayaan sebelum pembiayaan tersebut disalurkan pada nasabah, dimana penilaian tersebut berdasarkan analisi $5 C^{\prime \prime} .5$

Bank diharuskan melakukan penilaian yang seksama terhadap nasabahnya dengan melihat berbagai aspek, adapun penilaian tersebut dimaksudkan agar bank mempunyai keyakinan akan kemampuan dari calon debitur dalam memenuhi kewajibannya.

Prinsip pemberian pembiayaan dengan analisis 5C merupakan suatu penilaian yang sangat penting untuk menyimpulkan pencairan uang kepada nasabah dan ini merupakan prinsip kehati-hatian yang digunakan Bank Muamalat, dimana 5C meliputi:

1) Character merupakan sifat atau watak seseorang dalam hal ini calon debitur. Tujuannya adalah memberikan keyakinan kepada bank bahwa sifat ata watak dari seseorang yang akan diberikan pembiayaan benarbenar dapat dipercaya keyakinan ini tercermin dari latar belakang si nasabah, baik yang bersifat latar belakang pekerjaan maupun yang bersifat pribadi seperti: gaya hidup yang dianutnya, keadaan keluarga serta hobi dan status sosialnya. Character merupakan ukuran untuk menilai "kemauan" nasabah membayar hutangnya, karena orang yang memiliki karakter yang baik akan berusaha untuk membayar hutangnya dengan berbagai cara.

2) Capacity (Capability) digunakan untuk melihat kemampuan calon nasabah dalam membayar hutang yang dihubungkan dengan kemampuan mengelola bisnis serta kemampuannya mencari laba. Sehingga pada akhirnya akan terlihat kemampuannya dalam mengembalikan hutang yang disalurkan. Semakin banyak sumber pendapatan seseorang maka semakin besar pula kemampuan orang tersebut untuk membayar hutang.

3) Capital merupakan sumber dana atau modal dimana bank pada dasarnya tidak akan bersedia secara penuh untuk membiayai suatu

${ }^{5}$ Wawancara dengan Ashari Setya Selaku Staf Legal Bank Muamalat Cabang Denpasar pada tanggal 24 April 2019 pukul 10.25 WIB 
usaha kepada nasabah, karena setiap nasabah yang mengajukan pembiayaan harus pula menyediakan dana dari sumber lainnya atau modal sendiri dengan kata lain capital adalah untuk mengetahui sumber-sumber pembiayaan yang dimiliki oleh nasabah terhadap usaha yang akan dibiayai oleh bank.

4) Collateral merupakan jaminan yang diberikan calon nasabah baik yang bersifat fisik maupun non fisik. Jaminan hendaknya bernilai melebihi jumlah hutang yang diberikan. Jaminan juga wajib diteliti keabsahannya sehingga jika terjadi suatu masalah, jaminan yang dititipkan akan dapat dipergunakan secepat mungkin, adapun fungsi dari jaminan adalah untuk memberikan perindungan kepada bank dari resiko kerugian.

5) Condition of economy dimana dalam penilaian terhadap suatu pembiayaan hendaknya diperhatikan juga terkait dengan kondisi ekonomi saat ini ataupun di masa yang akan datang sesuai dengan sektor masing-masing. Dalam kondisi perekonomian yang kurang stabil, sebaiknya pemberian pembiayaan untuk sektor tertentu jangan diberikan terlebih dahulu dan kalaupun jadi diberikan sebaiknya juga harus melihat prospek usaha tersebut di masa yang akan datang.

Adapun secara garis besar tahapan proses pembiayaan mulai dari tahap pengajuan hingga pencairan pembiayaan dapat dijabarkan sebagai berikut:

a. Tahap pengajuan pembiayaan, yaitu :

1) Calon nasabah menghubungi petugas pelayanan pembiayaan dengan mendatangani bank pada hari atau jam kerja untuk mengisi formulir permohonan pembiayaan dan dilakukan wawancara pendahuluan secara singkat.

2) Petugas pelayanan pembiayaan melakukan pengecekan dan permintaan Informasi Debitur Individual (IDI) bank Indonesia kemudian menyusun dokumen yang diperlukan untuk diserahkan kepada bagian survei dan analisa.

b. Tahap Investigasi atau Analisis Pembiayaan oleh Staf Survei dan Analisa Pembiayaan, yaitu :

1) Petugas memastikan kelengkapan dokumen persyaratan pembiayaan dan mencocokkan data kemudian mempelajari berkas permohonan pembiayaan untuk memperoleh gambaran awal kondisi calon 
nasabah kemudian mempersiapkan hal-hal maupun peralatan yang akan dibawa ketika survei.

2) Petugas survei mencari informasi awal calon nasabah dari lingkungan sekitar, mewawancarai calon nasabah, mengambil foto usaha calon nasabah dan jaminan calon nasabah kemudian membuat denah lokasi.

3) Petugas membuat suatu analisa terhadap resiko dari pembiayaan dan melakukan analisa 6C yang meliputi charater, capacity, cashflow, condition, capital dan collateral. Petugas juga menguji kembali terkait dengan kebenaran informasi dan melakukan analisa terhadap jumlah permohonan pembiayaan dan rencana penggunaan pembiayaan serta menganalisa pinjaman calon nasabah di bank lain.

4) Setelah petugas melakukan survei dan analisis pembiayaan, petugas kemudian menyusun laporan survei dan analisa pembiayaan untuk diajukan kepada komite pembiayaan. Komite pembiayaan setelah melakukan review akan memutuskan apakah permohonan pembiayaan ditolak, disetujui dengan catatan ataupun disetujui sesuai permohonan.

5) Keputusan pembiayaan dituangkan secara tertulis dalam Surat Keputusan Pembiayaan (SKP). SKP untuk pembiayaan yang disetujui memuat data tentang jenis fasilitas pembiayaan, jumlah plafon pembiayaan, jangka waktu pembiayaan, margin atau bagi hasil, provisi pembiayaan, biaya administrasi pembiayaan, dan disposisi pemutus pembiayaan. SKP kemudian diberikan kepada manager pembiayaan untuk diserahkan kepada petugas administrasi pembiayaan.

c. Tahap Realisasi Pembiayaan

1) Petugas administrasi pembiayaan menerima berkas pembiayaan dari manager pembiayaan kemudian mempersiapkan administrasi untuk realisasi termasuk menghitung biaya realisasi, menguhubungi calon nasabah, menghubungi notaris rekanan untuk cek sertifikat, membuat surat pemberitahuan putusan pembiayaan kepada calon nasabah, membuat berita acara jaminan, dan mempersiapkan akad termasuk dimuat di dalamnya nama dan alamat nasabah, tujuan penggunaan dana, jangka waktu, nisbah bagi hasil, jumlah dan 
sistem pembayaran angsuran. Berkas tersebut diserahkan terlebih dahulu kepada supervisor administrasi pembiayaan untuk diperiksa.

2) Setelah cek atas jaminan berupa sertifikat dinyatakan bersih oleh notaris dan memperoleh kepastian sertifikat hak atas tanah dapat dipasang hak tanggungan maka petugas administrasi pembiayaan menghubungi calon nasabah untuk tahap realisasi pencairan pembiayaan di hadapan notaris dengan berkoordinasi terlebih dahulu dengan manager operasional.

3) Nasabah menandatangani akad pembiayaan berikut akta penyerahan dan pengikatan jaminan yang selanjutnya dibawa ke notaris yang ditunjuk selaku notaris rekanan dari bank untuk di legalisasi akad tersebut serta dilanjutkan dengan pengikatan jaminan oleh notaris yang bersangkutan dalam hal ini notaris mengeluarkan covernote yang merupakan surat keterangan bahwa jaminan sedang dalam proses.

4) Setelah nasabah menandatangani akad dan pengikatan notaris yang dibuktikan dengan adanya tanda tangan notaris dalam surat pegantar atau surat keterangan yang biasa disebut dengan istilah covernote dari notaris, maka petugas administrasi pembiayaan menyerahkan kepada manager operasional dokumen-dokumen terkait dan setelah dilakukan pencocokan dokumen dan ditandatangani oleh manager operasional maka nasabah diminta ke teller untuk menerima dana pencairan pembiayaan dan jadwal angsuran dari teller.

5) Setelah pencairan pembiayaan, maka berkas pembiayaan disusun rapi dalam berkas pembiayaan dan menyimpan dokumen jaminan asli di ruang penyimpanan dan petugas administrasi pembiayaan melakukan pantauan jaminan di dalam setiap proses sampai proses selesai dilakukan sesuai dengan Standar Waktu Selesai (SWS) dan jaminan asli diterima oleh bank dan notaris.

Berdasarkan uraian diatas maka dapat diambil kesimpulan bahwa surat keterangan notaris atau biasa disebut dengan covernote memegang peranan yang penting dalam pelaksanaan pencairan pembiayaan, dimana covernote digunakan sebagai bukti pengikatan jaminan dan pegangan sementara bagi bank dalam mencairkan pembiayaan. 


\section{Tanggung Jawab Notaris dalam Pembuatan Covernote}

Notaris adalah pejabat umum yang diberikan wewenang oleh undang-undang yang dimana setiap perbuatan yang dilakukan oleh notaris diatur didalam undang-undang yang mengharuskan notaris untuk tunduk pada ketentuan yang ada di dalamnya. Untuk menghindari kesalahan dalam pelaksanaan jabatan sehingga menimbulkan dampak dengan adanya kerugian baik terhadap diri notaris sendiri maupun para pihak yang berhubungan langsung dengan notaris. Dengan begitu seorang notaris dituntut untuk memahami dengan seksama secara utuh segala sesuatu yang berkenaan dengan Undang-undang Jabatan Notaris.

Berdasarkan wawancara yang telah dilakukan penulis dengan salah satu narasumber dalam hal ini adalah notaris, dimana notaris tersebut mengatakan bahwa "notaris adalah jabatan kepercayaan sehingga seseorang bersedia untuk mempercayakan sesuatu kepadanya sehingga notaris berkewajiban untuk merahasiakan segala sesuatu yang telah diberitahukan kepadanya meskipun terdapat hal-hal yang memang tidak dicantumkan di dalam akta karena nama baik serta jabatan notaris dipertaruhkan oleh notaris dalam setiap hal yang telah notaris keluarkan terkait dengan jabatannya. ${ }^{6}$

Covernote dalam praktiknya dibuat oleh seorang notaris yang merangkap sebagai PPAT dimana notaris tersebut telah menjadi rekanan suatu bank ataupun bank syariah, dimaa covernote digunakan sebagai surat keterangan yang dibuat untuk menjelaskan bahwa penandatanganan akta telah benar-benar dilakukan oleh bank dan nasabah dihadapan notaris, covernote yang merupakan surat keterangan memiliki kaitan dengan suatu pembiayaan yang diikat dengan hak tanggungan yng didalamnya berisi keterangan bahwa sertipikat yang menjadi agunan sedang dalam proses di kantor notaris-PPAT yang bersangkutan, dimana dengan pemasangan hak tanggungan tersebut memerlukan waktu yang tidak sebentar dan tidak dapat diselesaikan pada waktu itu juga.

Tanggung jawab notaris terkait dengan covernote yang telah dikeluarkannya dimulai sejak pembuatan dari covernote dimana dalam covernote tersebut menerangkan bahwa notaris akan menyelesaikan tugasnya terkait dengan hak tanggungan sesuai dengan waktu yang telah ditentukan di dalam covernote, adanya rasa percaya bank kepada notaris dalam menyelesaikan tugasnya inilah yang berhubungan dengan tanggung jawab notaris meskipun hal yang terkait dengan covernote tidak diatur di dalam Undang-Undang Jabatan Notaris, namun menjadi suatu kebiasaan yang menyangkut nama baik serta tanggung jawab moral bagi notaris dalam

6 Wawancara dengan Notaris Ambo Enre, SH selaku notaris rekanan Bank Muamalat pada tanggal 29 April 2019 pukul 11.35 WIB 
menjalankan profesinya. Berdasarkan wawancara yang telah penulis lakukan dengan salah seorang notaris yang berpendapat bahwa "covernote dikeluarkan atau dibuat sebagai alternatif pemecahan masalah terkait dengan lamanya waktu yang diperlukan dan dibutuhkan oleh notaris dalam mengurus hal-hal yang terkait dengan hak tanggungan, dimana waktu yang biasanya diperlukan sekitar tiga hingga enam bulan, karena inilah bank sangat memerlukan covernote agar proses pencairan dana pembiayaan dapat terselesaikan dengan segera."7

Dasar pembuatan dari covernote memang tidak diatur di dalam Undang-Undang Jabatan Notaris sehingga covernote bukan merupakan tugas pokok dari seorang notaris-PPAT. Namun pada praktiknya notaris dapat mengeluarkan covernote berdasarkan permintaan dari bank sebagai dasar kepercayaan bank kepada notaris. Oleh karena itu seorang notarisPPAT dalam menerbitkan covernote harus memiliki sikap hati-hati sehingga apa yang telah notaris terangkan dalam covernote merupakan kebenaran terhadap apa yang notaris kerjakan.

Dengan dikeluarkannya covernote oleh notaris maka tanggung jawab notaris terhadap covernote tersebut sangatlah besar karena secara tidak langsung covernote menjadi ujung tombak dari proses percepatan pencairan pembiayaan khususnya pembiayaan KPR, munculnya covernote dikarenakan adanya kebutuhan praktik yang mendesak sehingga pihakpihak tertentu dalam pelaksanaan pembiayaan memerlukan covernote. Tidak ada dasar hukum dari penerbitan covernote, tetapi dalam praktiknya covernote menjadi sangat penting keberdaannya, dan oleh karenanya covernote hanya mengikat secara moral dan muncul berdasarkan praktik dan kebutuhan, dan bentuk mengikatnya itu hanya terletak pada notaris apabila notaris tidak menyangkal tandatangannya. Karena covernote mengikat notaris maka notaris mempunyai tanggung jawab yang sangat besar terhadap covernote yang teah dikeluarkan, karena didalam covernote memuat janji-janji sehingga apabila hal-hal yang tertulis di dlam covernote tidak sesuai dengan yang diperjanjikan maka notaris itulah yang akan menanggung akibatnya atau yang akan mendapatkan tuntutan dari pihak bank dan debitor.

\section{Akibat Hukum dari Pembuatan Covernote yang Dijadikan Dasar dalam Perjanjian Pembiayaan di Perbankan Syariah.}

Covernote bukanlah akta autentik, karena bukan produk resmi Notaris dan tidak ditegaskan dalam undang-undang perihal kewenangan

${ }^{7}$ Wawancara dengan Notaris M. Taufiqurrahman, SH.,MKn pada tanggal 12 Juni 2019 pukul 13.35 WIB 
Notaris, untuk mengeluarkan covernote. Karena akta autentik syaratnya harusnya bentuknya dibuat sesuai dengan perundang-undangan dan dibuat oleh dan dihadapan pejabat yang berwenang sedangkan covernotetidak memiliki kriteria akta autentik tetapi hanya berupa surat keterangan yang dikeluarkan oleh Notaris. Covernote yang dikeluarkan oleh Notaris juga bukan dijadikan sebagai bukti agunan, akan tetapi hanya sebagai pengantar pada Bank yang akan mengeluarkan kredit, covernote bagi instansi yang memerlukan bukan juga berarti sebagai kelengkapan berkas akan tetapi sebagai jaminan bahwa ternyata benar berkas yang dibutuhkan instansi atau klien adalah benar-benar dalam proses, setidaknya ada kepercayaan yang terbangun antara notaris dengan Bank, antara Notaris dengan Instansi, dan juga antara notaris dengan Klien.

Notaris yang mengeluarkan covernote bukanlah sekedar memberikan surat keterangan baik mengenai jaminan debitur sebagai pemberi hak tanggungan maupun jaminan kelengkapan berkas pada suatu instansi. Tentu saja dalam mengeluarkan covernote tersebut ada konsekuensi hukumnya, apabila dalam perjalan proses penerbitan sertifikat hak tanggunan terjadi masalah dan berlarut-larut dalam penyelesaiannya, baik kendala dalam proses pemecahan seritikat, balik nama, ataupun kendala lain yang terjadi dalam serangkaian proses penerbitan sertifikan hak tanggungan, hal ini dapat membawa permasalahan dikemudian hari.

Peraturan perundang-undangan sebagian besar ada yang dipatuhi dan ada juga yang tidak dipatuhi. Sistem hukum yang jelas akan runtuh jika setiap orang tidak mematuhi undang-undang sehingga undang-undang dapat kehilangan maknanya. Tidak efektifnya undang-undang cenderung mempengaruhi waktu, sikap dan kuantitas ketidakpatuhan serta mempunyai efek nyata terhadap perilaku hukum, termasuk perilaku melanggar hukum. Kondisi ini tentunya akan mempengaruhi penegak hukum yang menjamin kepastian hukum serta keadilan dalam masyarakat.

Sedangkan kepastian karena hukum dimaksudkan karena dengan hukum itu sendirilah adanya kepastian, misalnya hukum menentukan adanya lembaga daluarsa, dengan lewat waktu seseorang akan mendapatkan hak atau kehilangan hak. Berarti hukum dapat menjamin adanya kepastian bagi seseorang dengan lembaga daluarsa akan mendapatkan sesuatu hak tertentu atau akan kehilangan hak tertentu.

Jika hukum diidentikkan dengan perundang-undangan, maka salah satu akibat yang dapat dirasakan adalah jika ada bidang kehidupan yang belum diatur dalam perundang-undangan, maka dapat dikatakan jika hukum tertinggal oleh perkembangan masyarakat. Demikian juga kepastian tidak identik dengan kepastian undang-undang, apabila kepastian hukum dilakukan tanpa memperhatikan kenyataan hukum yang berlaku. 
Notaris dalam menjalankan tugas jabatannya harus berdasarkan wewenang yang telah ada pada jabatan notaris itu sendiri, dimana wewenang dariseorang notaris telah disebutkan dalam Pasal 15 UndangUndang Jabatan Notaris Nomor 2 Tahun 2014, kewenangan notaris tersebut terdapat dalam Pasal 15 dari ayat (1) sampai dengan ayat (3) UUJN, yang dapat dibagi menjadi 3 yaitu :

a. Kewenangan umum notaris

Terdapat di dalam Pasal 15 ayat (1) Undang-Undang Jabatan Notaris Nomor 2 Tahun 2014 yang menegaskan bahwa salah satu kewenangan notaris, yaitu membuat akta secara umum (hal ini disebut sebagai kewenangan umum notaris);

b. Kewenanangan khusus notaris

Terdapat di dalam Pasal 15 ayat (2) Undang-Undang Jabatan Notaris Nomor 2 Tahun 2014 mengatur mengenai kewenangan khusus notaris untuk melakukan tindakan hukum tertentu;

c. Kewenangan notaris yang akan ditentukan kemudian, Pasal 15 ayat

(3) Undang-Undang Jabatan Notaris Nomor 2 Tahun 2014.

Berkaitan dengan wewenang tersebut, jika notaris melakukan tindakan di luar wewenang, maka produk atau akta notaris tersebut tidak mengikat secara hukum atau tidak dapat dilaksanakan, dan pihak yang merasa dirugikan oleh tindakan notaris yang berada diluar wewenag tersebut, maka notaris dapat digugat secara perdata ke pengadilan negeri, dengan kata lain bahwa covernote bukan merupakan kewenangan notaris tetapi tidak dilarang untuk dibuat oleh notaris, dengan ketentuan jika covernote itu bermasalah dikemudian hari karena isinya tidak benar, maka hal tersebut menjadi tanggung jawab dari notaris sepenuhnya dengan segala akibat hukumnya, karena notaris membuat atau mengeluarkan covernote diluar kewenangannya sebagai notaris.

Meskipun di dalam praktik yang ada di Bank Muamalat Cabang Denpasar belum pernah terjadi wanprestasi terkait dengan covernote, namun apabila dikemudian hari terjadi masalah wanprestasi terkait dengan covernote, maka notaris dapat terkena sanksi baik secara perdata ataupun sanksi secara administrasi, yang akan dijelaskan sebagai berikut:

1. Sanksi secara perdata yaitu apabila dalam notaris tidak bisa menyelesaikan tugasnya seperti yang ada di dalam covernote, meskipun notaris sudah meminta perpanjangan waktu ataupun pembuatan covernote yang baru. Sehingga pihak bank merasa dirugikan maka pihak bank dapat menuntut Notaris secara perdata ke pengadilan karena tidak dapat menyelesaikan tugasnya secara baik atau tuntas sehingga menimbulkan kerugian. 
2. Sanksi secara administrasi, hal ini dapat terjadi karena covernote bukan merupakan kewenangan bagi notaris sesuai dengan ketetntuan Pasal 15 Undang-Undang Jabatan Notaris terkait dengan kewenanangan notaris, dikeluarkannya covernote hanya berdasarkan praktik kebiasaan yang ada di lingkupan notaris dan perbankan khususnya perbankan syariah, sehingga dalam hal ini notaris juga dapat dikenakan sanksi administrasi sesuai dengan Pasal 6 ayat 1 Kode Etik Notaris, dimana notaris dapat dikenakan sanksi berupa :

a. Teguran lisan;

b. Teguran tertulis;

c. Pemberhentian sementara dari keanggotaan perkumpulan;

d. Pemberhentian dengan hormat dari keanggotaan perkumpulan;

e. Pemberhentian dengan tidak hormat dari keanggotaan perkumpulan.

Dalam melaksanakan tugas dan jabatannya seorang notaris harus berpegang teguh pada kode etik jabatan notaris sebab tanpa itu, harkat dan martabat profesionalisme akan hilang.

Kode etik notaris sendiri merupakan suatu ketentuan yang mengatur tingkah laku notaris dalam melaksanakan jabatannya, juga mengatur hubungan sesama rekan notaris, sehingga pada hakekatnya kode etik notaris merupakan penjabaran lebih lanjut dari apa yang diatur dalam Undangundang Jabatan Notaris. ${ }^{8}$

\section{KESIMPULAN}

Praktik pembuatan covernote oleh notaris diawali dengan adanya tahap pengajuan pembiayaan oleh nasabah, dilanjutkan dengan tahap investigasi atau analisis pembiayaan oleh Staf Survei dan Analisa Pembiayaan, Tahap Realisasi Pembiayaan dimana di dalam tahap ini notaris selaku rekanan Bank Muamalat akan mengeluarkan covernote atau surat keterangan terkait dengan jaminan dan Hak Tanggungan, dan dilanjutkan dengan proses pencairan dana pembiayaan bagi nasabah.

Tanggung jawab notaris terkait dengan covernote yang telah dikeluarkannya dimulai sejak pembuatan dari covernote dimana dalam covernote tersebut menerangkan bahwa notaris akan menyelesaikan tugasnya terkait dengan hak tanggungan sesuai dengan waktu yang telah ditentukan di dalam covernote, adanya rasa percaya bank kepada notaris dalsam menyelesaikan tugasnya inilah yang berhubungan dengan tanggung jawab notaris meskipun hal yang terkait dengan covernote tidak diatur di

\footnotetext{
${ }^{8}$ Abdul Wahid, Sunardi, dan Mariyadi, Penegakan Kode Etik Profesi Notaris,
} (Jakarta: Nirmana Media, 2017), hal. 148-149 
dalam Undang-Undang Jabatan Notaris, namun menjadi suatu kebiasaan yang menyangkut nama baik serta tanggung jawab moral bagi notaris dalam menjalankan profesinya.

Akibat hukum dari dikeluarkannya covernote adalah karena adanya unsur jaminan yang telah diberikan oleh nasabah, sehingga covernote dikeluarkan agar terdapat kepastian hukum bagi bank khususnya dan juga nasabah. Adapun terkait dengan masalah wanprestasi, di dalam praktiknya khususnya di perbankan Bank Muamalat Cabang Denpasar, sepanjang Bank Muamalat Cabang Denpasar beroperasi belum ada kasus terkait adanya wanprestasi baik itu dari nasabah maupun notaris selaku notaris rekanan Bank Muamalat sebagai pihak yang membuat covernote, notaris ataupun pihak bank dapat mengajukan perpanjangan waktu ataupun penerbitan covernote yang baru sesuai dengan batas waktu yang dibutuhkan. Namun apabila setelah perpanjangan waktu atau penerbitan covernote yang baru tugas notaris yang ada di dalam covernote belum terselesaikan maka notaris dapat dikenakan sanksi berupa sanksi perdata ataupun sanksi administrasi.

\section{DAFTAR PUSTAKA}

Abdulkadir Muhammad, 1997, Etika Profesi Hukum, Bandung: Citra Adtya. Abdul Wahid, Sunardi, dan Mariyadi, 2017, Penegakan Kode Etik Profesi Notaris, Jakarta: Nirmana Media.

Adnan Buyung Nasution, 2001, Inspirasi Pemerintahan Konstusional Indonesia (studi Sosio-Legal atas Konstituante 1956-1959), Jakarta: Temprint.

Ronny Hanitijo Soemitro, 1994, Pengantar Penelitian Hukum, Jakarta: Ghalia.

Supardi, Etika dan Tanggung Jawab Profesi Hukum di Indonesia, Jakarta: Sinar Grafika. 
TANGGUNG JAWAB NOTARIS DALAM MENGELURKAN COVERNOTE DALAM PERJANJIAN

PEMBIAYAAN DI PERBANKAN SYARIAH (Desy Amelia Rosyidah)

176 